JOSAR, Vol. 1 No. 2 September, 2018; p-ISSN: 2502-8251; e-ISSN: 2503-1155

Copyrights@ Balitar Islamic University, Blitar-Indonesia

https://ejournal.unisbablitar.ac.id/index.php/josar

\title{
COST PLUS PRICING METHOD \\ IN DETERMINING THE SELLING PRICE OF THE BANANA CHIPS \\ (Study at UD. Anisa Jaya Gogodeso Village)
}

\author{
Istika Risvanti ${ }^{1)}$, Endah Masrunik ${ }^{2)}$ \\ ${ }^{1,2}$ Islamic University of Balitar; JI. Majapahit No.04, Telp. (0342) 813145 \\ Ekonomics Faculty, Islamic Universitas of Balitar,Blitar \\ E-mail : istyka11risvanti96@gmail.com ${ }^{1)}$, endahmasrunik@gmail.com ${ }^{2)}$
}

\begin{abstract}
UD. Anisa Jaya is located on Arjuno Street Rt 02 Rw.07, Gogodeso Dusun Ngade, Kanigoro Sub-District, Blitar District. This business produces various kinds of products such as banana chips, kardol and others. The researcher focused on banana chips. The aim of the study was to find out the determination of the selling price of banana chips at UD. Anisa Jaya with company methods and cost plus pricing methods. This type of research is quantitative. The data used are primary data and secondary data. From the results of interviews and observations, researchers found the data needed to complete the needed data. Secondary data in the form of organizational structures, documents and business profiles. The results of the study indicate that the selling price set by the company is lower than IDR 1,567 rather than the cost plus pricing method. With the method of selling the selling price used is Rp. 8,000 per pack while the cost plus pricing method is Rp. 9,567. This is because the company does not include all factory overhead costs used in calculating the cost of production while the researcher includes all factory overhead costs in its calculations.
\end{abstract}

\section{Keywords: Cost of Sales, Selling Price, Cost Plus Pricing}

\section{INTRODUCTION}

East Java is one area that is rich in natural resources, one of them is banana. The contribution of bananas to Indonesia is $21.8 \%$. This can be used as an opportunity to open a banana-based material business. By opening a business, it will also absorb labor around the home or area used for the place of business so that it will reduce unemployment. With the opportunity to open the business, it can be used as a daily livelihood or as a side. According to the Central Agency Statistics business is an economic unit that carries out activities with the aim of producing goods or services for the purpose of earning profits or other financial benefits for the owner.

The era is increasingly modern and growing, business competition is getting tougher. Not only that, competition entering the workforce even more difficult because of the many graduates who will look for work. Skills and experiences learned during school will be very useful if they 
can be utilized properly. A business must have good management to manage the company so that there is no loss. In addition, management also has to take care the costs of the materials needed in the production process. For that, cost accounting is needed to find out the financial statements used to make the product. Cost accounting is one of the fields in accounting that studies how to measure, record, and report the information on costs used by companies [1]. So that, the costs incurred can be monitored.

Costs incurred in the production process from start to finish are called production costs. Cost is the cost of goods or services that have provided benefits that can be used to obtain unit of income [2]. So costs arise as a result of carrying out an activity that will cause expenditure. Production costs consist of raw material costs are costs incurred because of buying materials for production, labor costs are costs incurred due to using human labor, and factory overhead costs are production costs that arise in addition to raw material costs and labor costs [3]. The production costs are then added to the initial inventory of finished products and are reduced by the final inventory of finished goods. So that, the cost of goods sold will determine the selling price. The selling price is a number of costs incurred by the company to produce an item or service to be transplanted with the percentage of profit that the company wants [4]. One way to determine the selling price is the cost plus pricing method, which is the selling price for one unit of goods which is equal to the total cost of the unit plus the desired amount of margin [4]. In the previous study, the results of selling price determination using full costing were higher than the company method, where the difference was Rp. $253,612.69$ [5]. It is because the full costing method includes all elements of costs. Likewise in the previous research the price set by the company was greater than the price of the analysis of the cost of production [6]. It is because there is a difference in factory overhead cost. Based on previous research, it can be seen if the company is not careful and uses the wrong method so that the selling price is more expensive or lower 
than the price that should use the method. This research will discuss the selling price of banana chips which are produced by UD. Anisa Jaya. UD. Anisa Jaya is one of the businesses that is engaged in snacks. In its production, the costs are definitely needed from the beginning of the production process to the final stage of packaging.

\section{RESEARCH METHODS}

The research used is quantitative research. This study uses numbers as a tool to analyze. The variable in the study is a free variable is the cost of goods sold which affects the selling price and the dependent variable is the selling price. Sources of data used in primary data research in the form of data obtained by storing and interviewing directly to the place of research, and secondary data is data collected by other parties, researchers use only what is needed. Secondary data in the form of an overview, and organizational structure at UD. Anisa Jaya. In the form of data collection techniques: observation method, by coming directly to UD. Anisa Jaya; documentation method, in the form of data at UD. Anisa Jaya covers organizational structure, product data, company history; interview method, the researcher conducted a question and answer to the owner of UD. Anisa Jaya. The data analysis technique performed is calculating the cost of goods sold and then calculating the selling price using cost plus pricing.

The cost elements into production costs are two approaches [3]. One of them is the full costing method is a method of determining production costs that takes into account all elements of production costs into production costs, which consist of raw material costs, direct labor costs, and factory overhead costs, both variable and fixed behavior.

\begin{tabular}{|lc|}
\hline \multicolumn{2}{|c|}{ Full Costing Method: } \\
\hline Raw materials cost & $\mathrm{xxx}$ \\
\hline Direct labor cost & $\mathrm{xxx}$ \\
\hline Overhead factory variable cost & $\mathrm{xxx}$ \\
\hline Overhead factory permanent cost & $\underline{\mathrm{xx}+}$ \\
\hline Production cost & $\mathrm{xxx}$ \\
\hline
\end{tabular}


After the production costs are obtained, calculate the cost of goods sold. The cost of goods sold formula is:

\begin{tabular}{|c|c|c|c|}
\hline \multirow{2}{*}{\multicolumn{2}{|c|}{$\begin{array}{l}\text { Initial inventory of finished products } \\
\text { Cost of production }\end{array}$}} & \multicolumn{2}{|r|}{$X x x$} \\
\hline & & & \\
\hline Initial inventory of goods in process & & $x X x$ & \\
\hline Cost of production: & $\mathrm{Xxx}$ & & \\
\hline Raw materials cost & $X x x$ & & \\
\hline Direct labor cost & $X x x$ & & \\
\hline Overhead variable cost & $\mathrm{Xxx}$ & & \\
\hline Overhead permanent cost & $x x+$ & & \\
\hline & & $x x x+$ & \\
\hline & & $x \times x$ & \\
\hline Final inventory of goods in process & & $\mathrm{XXX}$ & \\
\hline Total production cost & & & $\mathrm{XXX}+$ \\
\hline Goods available for sale & & & $x X X$ \\
\hline Final Supplies of Finished Goods & & & $\mathrm{XXX}-$ \\
\hline Cost of Goods Sold & & & $\mathrm{XXX}$ \\
\hline
\end{tabular}

Then calculate the selling price of banana chips with the cost plus pricing method [3]. Formula: Selling Price $=$ Total Cost + Margin

\section{RESULTS AND DISCUSSION}

\section{Raw Materials}

The raw material used for the process of making banana chips are 2 tons of banana or $2000 \mathrm{~kg}$ of banana, $75 \mathrm{~kg}$ of sugar and cooking oil for frying bananas as much as 240 liters.

\section{Table 1}

Raw Materials Cost

\begin{tabular}{|l|l|l|l|}
\hline \multicolumn{1}{|c|}{ m } & \multicolumn{1}{c|}{ Unit } & Price & Total \\
\hline Banana & $2000 \mathrm{~kg}$ & $\mathrm{Rp} 6.000$ & $\mathrm{Rp} 12.000 .000$ \\
\hline Sugar & $75 \mathrm{~kg}$ & $\mathrm{Rp} 11.000$ & $\mathrm{Rp} 825.000$ \\
\hline Oil & $240 \mathrm{~L}$ & $\mathrm{Rp} 10.000$ & Rp 2.400 .000 \\
\hline \multicolumn{3}{|c|}{ Total } & Rp 15.225.000 \\
\hline
\end{tabular}

Source: Data processed 2018

\section{Labor Cost}


Wages for labor are IDR 25,000 / day. Where there are 10 working days in one production of banana chips.

Table2

Labor Cost

\begin{tabular}{|c|l|l|c|l|}
\hline Element & Unit & Day & Wage & Total \\
\hline Wage & 6 & 10 & Rp25.000 & Rp1.500.000 \\
\hline \multicolumn{4}{|c|}{ Total } & Rp1.500.000 \\
\hline
\end{tabular}

Source: Data processed 2018

\section{Factory Overhead Cost}

\section{Gas Cost}

Gas costs are used by companies because they use gas as fuel to fry banana chips. In one production of banana chips, the company spent 120 tubes.

2. Vehicle Fuel Costs

Transportation costs used to purchase raw materials and short distance delivery of fuel needed $\pm R p 150,000$. which is used for 2 motors.

3. Electricity Cost

The electricity cost used to produce banana chips is a pump for water 30 minutes a day. So for about 10 days, use about 5 hours and the hand sealer machine to press plastic is used for 1 hour so it is used for 10 days for 10 hours.

4. Vehicle Maintenance Costs

Maintenance of vehicles such as anti-oil services and services will definitely need a cost. The amount of vehicle maintenance costs is Rp. 83,000.

5. Transportation Costs

The cost of fuel used for shipping goods at a distance in one shipment costs approximately Rp. 750,000. The fee also includes shipping costs for shipping.

6. Helper cost 
The main ingredients are auxiliary materials used in making banana chips such as flavorings, plastic for wrapping chips, stickers for food labels and expiration dates and other ingredients in making chips. The company used plastic as an ingredient to package banana chips. Plastic is used around 9 rolls. For the sticker, around 350 sheets are needed per production at a price of Rp. 5.00 per sheet. For flavorings in one production, the cost is Rp. 150.00 and for other spices needed in the process of making chips, Rp. 180,000.

\section{Depreciation Costs}

The tools used for the production of chips include gas cylinders, stoves, frying, spoon, tubs for washing bananas, trays for chips that have been fried, knife for cooking bananas. In addition there is also a hand sealer used to press plastic used for packing chips. And also a laptop that is used for financial records.

Table 3

Factory Overhead Cost

\begin{tabular}{|c|c|c|}
\hline Element & Total & \\
\hline \multicolumn{3}{|c|}{ Overhead factory variable cost } \\
\hline Gas Cost & $\mathrm{Rp}$ & 2.040 .000 \\
\hline Vehicle Fuel Costs & $\mathrm{Rp}$ & 75.000 \\
\hline Electricity Cost & $\mathrm{Rp}$ & $19.217,7$ \\
\hline Vehicle Maintenance Costs & $\mathrm{Rp}$ & 83,000 \\
\hline Transportation Cost & $\mathrm{Rp}$ & 1.200 .000 \\
\hline Helper Cost & $\mathrm{Rp}$ & 3.178 .000 \\
\hline \multicolumn{3}{|c|}{ Permanent Factory Operating Costs } \\
\hline Depreciation Cost & $\mathrm{Rp}$ & $577.437,5$ \\
\hline Total & \multicolumn{2}{|c|}{$\operatorname{Rp} 7.172 .655 .2$} \\
\hline
\end{tabular}

Source: Data processed 2018

Can be seen in the large table of the costs incurred for factory overhead costs of Rp. 7,172,655.2

\section{Production Cost}

In the table above, it can be seen the total production costs for chips for one production amounted to Rp. $23,986,873$ by producing 3400 packets. Each pack of production costs is Rp. 7,055 


\section{Cost of Goods Sold}

Table 5

Cost of Goods Sold

\begin{tabular}{|c|c|c|c|}
\hline $\begin{array}{l}\text { Initial preparation of } \\
\text { finished products }\end{array}$ & & & $\begin{array}{l}\mathrm{Rp} \\
10.000 .000\end{array}$ \\
\hline Cost Production & & & \\
\hline $\begin{array}{l}\text { Initial inventory of } \\
\text { goods in process }\end{array}$ & & $\mathrm{Rp}$ & \\
\hline Production Cost : & & & \\
\hline Raw Material Cost & Rp 15.225.000 & & \\
\hline Direct Labor Cost & Rp 1.500 .000 & & \\
\hline $\begin{array}{l}\text { Overhead Variable } \\
\text { cost }\end{array}$ & Rp $\quad 6.684 .435$ & & \\
\hline $\begin{array}{l}\text { Overhead Permanent } \\
\text { Cost }\end{array}$ & $\mathrm{Rp} \quad 577.438$ & & \\
\hline Cost Production & & Rp 23.986.873 & \\
\hline $\begin{array}{l}\text { Final inventory of items } \\
\text { in process }\end{array}$ & & $\mathrm{Rp}$ & \\
\hline $\begin{array}{l}\text { Total of Production } \\
\text { Cost }\end{array}$ & & & $\begin{array}{l}\mathrm{Rp} \\
23.986 .873\end{array}$ \\
\hline $\begin{array}{l}\text { Goods Available For } \\
\text { Sale }\end{array}$ & & & $\begin{array}{l}\mathrm{Rp} \\
33.986 .873 \\
\end{array}$ \\
\hline $\begin{array}{l}\text { Final Supplies of } \\
\text { Finished Goods }\end{array}$ & & & $\begin{array}{l}\text { Rp } \\
6.880 .000\end{array}$ \\
\hline Cost of Goods Sold & & & $\begin{array}{l}\mathrm{Rp} \\
27.106 .873\end{array}$ \\
\hline $\begin{array}{l}\text { Cost of goods sold per } \\
\text { Unit }\end{array}$ & & & $\begin{array}{l}\mathrm{Rp} \\
7.973\end{array}$ \\
\hline
\end{tabular}

Source: Data processed 2018

The researcher will determine the selling price with the cost-plus pricing method because UD. Anisa Jaya wants profit of $20 \%$ of the total cost. The cost plus pricing formula is as follows:

Selling Price $=$ Estimated full cost + Expected profit .

$\begin{array}{lcc}\text { Cost of Goods Sold } & \mathrm{Rp} & 27.106 .873 \\ \text { Profit } 20 \% & \mathrm{Rp} & 5.421 .375+ \\ \text { Selling Price } & \mathrm{Rp} & 32.528 .248 \\ \text { Unit } & & 3.400 \\ \text { Per unit selling price } & \mathrm{Rp} & 9.567 \\ \text { Profit per unit } & \mathrm{Rp} & 1.084\end{array}$

From the income above the selling price processed for one packet of banana chips is $\operatorname{Rp} 9,567$ 
Table 6

Comparison of Selling Prices

\begin{tabular}{|l|c|cc|c|}
\hline \multirow{2}{*}{ Information } & Company & \multicolumn{2}{c|}{$\begin{array}{c}\text { Cost Plus } \\
\text { Pricing }\end{array}$} & Difference \\
\cline { 2 - 5 } & Total & Total & Total \\
\hline Per unit selling price & $\mathrm{Rp} \quad 8.000$ & $\mathrm{Rp} \quad 9.567$ & $\mathrm{Rp} \quad 1.567$ \\
\hline
\end{tabular}

Source : Data processed 2018

\section{DISCUSSION}

The selling price set by the company is lower than the selling price obtained by researchers from the cost plus pricing method with a difference of $\mathrm{Rp} \mathrm{1,567.} \mathrm{Where} \mathrm{the} \mathrm{selling} \mathrm{price} \mathrm{used} \mathrm{by} \mathrm{the} \mathrm{company} \mathrm{is}$ Rp. 8,000 while the costing by pricing plus pricing method is Rp. 9.567.

The difference in selling prices is because the company does not include all costs that are issued in detail so that the results are less precise and accurate. The company only includes raw material costs, labor costs, gas purchase costs, transportation costs to buy raw materials, and helper costs. While researchers consider all costs used, namely raw material costs, labor costs, gas purchase costs, transportation costs, electricity costs, shipping costs and fuel, vehicle maintenance costs, long-term raw material costs, and equipment and building depreciation costs. This is the same as the research conducted by [7] the selling price set by the company is smaller while the researcher is bigger. This is because the calculation of the method applied by factory does not specify all costs incurred during the production process.

This research is similar to the one carried out by [8] where the selling price made by the owner is not a selling price that results in a large profit for the owner because the profit percentage is very small, very far compared to the selling price calculated by the researcher. A similar statement expressed by [9] by using cost plus pricing, the selling price of each variety is more varied. Similarly, research belongs to [10] the selling price set by the company is cheaper than the price based on the results of the researcher. 
Different from the research conducted by [11] where the selling price set by the company is higher than the selling price calculated based on the cost plus pricing method and mark up pricing. Similar to the research conducted by [12] the results of the study show that the calculation of the cost of goods made by the company is higher than the cost of the product after being evaluated by researchers whose selling price at the company is higher than the selling price set by researcher. The research carried out by [13] based on the results of the calculation of cost of production with the full costing method was lower than what was done by the company because the company's factory overhead costs were higher than the full costing method overhead. The research conducted by [14] the results of research showing the meaning of the variable costing method proved to achieve profits desired by the company but not with the selling price, because the selling price is still too high.

\section{CONCLUSION}

The selling price set by UD. Anisa Jaya is lower than the calculation of researchers by using cost plus pricing with a difference of $R p 1,567$. In the company the selling price of banana chips is $\mathrm{Rp}$. 8,000 while the cost plus pricing is Rp. 9,567. This is because the company does not include all costs incurred for production so that the cost of production is not optimal. So that, the selling price is also important because it is related to each other.

\section{SUGGESTION}

The company should use the right method to calculate the cost of production so that it is more detailed and accurate. So that there will be no missed costs.

\section{ACKNOWLEDGEMENT}

Thank you to all parties involved in completing this journal. 


\section{REFFERENCES}

[1] Bustami, Bastian and Nurlela. 2010. Cost Accounting. Jakarta: Mitra Wacana Media

[2] Siregar, et al. 2014. Cost Accounting. Second edition. Jakarta: Mitra Wacana Media

[3] Mulyadi. 2015. Fifth Edition Cost Accounting. 13.th print of Yogyakarta: UPP STIM YKPN

[4] Private, Basu. 2007. Azaz-Azaz Marketing. Revised Edition. Yogyakarta: Business Finance Academy (AKB)

[5] Anita, Utcik. 2013. Analysis of Calculation of Cost of Production as a Baseline for Determining Selling Prices of Furniture Products (Case study at PT. Hanin Design Indonesia- Indonesia Legal Wood). 1-10 EMBA Journal. Economics and Business Faculty of Accounting: Dian Nuswantoro University, Semarang

[6] Erawati. Lili Syafitri. 2013. Analysis of Cost of Production as a basis for Selling Price at CV Harapan Inti Usaha Palembang. Journal of EMBA 1-9. Accounting Department: STIE MDP

[7] Setiyaningsih, Endra. 2009. Analysis of the Application of the Full Costing Method in Calculating Cost of Production to Establish Selling Prices (Case Study at Tofu Lestari Factory). EMBA Journal 1-16. Economics and Business Faculty: Dian Nuswantoro University

[8] Ikawati, Abriyana, 2017. Determination of Selling Prices by Cost Plus Pricing Method for Simple Stalls 2 Jetsi Kulon Surabaya. EMBA Vol5 No. 2 Journal 1-21. Surabaya State University

[9] Gayatri, Winny. 2013. Product Selling Price Determination as a Cost Plus Pricing Method at PT. Farmers (PERSERO) North Sulawesi Branch. EMBA Journal Vol 1 No. 4 pp. 1817-1823 Faculty of Business Economics, Quantity Department. Sam Ratulangi University Manado

[10] Marsalina, Ira. Nurita Affan. Raden Priyo Utomo. 2011. Analysis of Determination of Main Production Cost in Establishing Selling Prices of Bottled Drinking Water in PDAM Tirta Mahakanm Kutai Kartanegara. Journal of EMBA 1-21. Economic Faculties of Mulawarman University

[11] Toar, Oktavia Herman Karamoy, Heince Workas. 2017. Comparison of Selling Price Products Analysis Using the Cost Plus Pricing Method and Mark Up Pricing at Dolphin Donuts Bakery. EMBA 
JOSAR, Vol. 1 No. 2 September, 2018; p-ISSN: 2502-8251; e-ISSN: 2503-1155

Copyrights@ Balitar Islamic University, Blitar-Indonesia https://ejournal.unisbablitar.ac.id/index.php/josar

Journal Vol 5 No. 2 2040-20150. Economics and Business Faculty of Accounting: Sam Ratulangi University, Manado

[12] Slat, Andre. 2013. Main Price Analysis with Full Costing Method and Selling Price Determination. Journal of EMBA 110-117. Economics Faculty of Accounting: Sam Ratulangi University, Manado

[13] Coal, Helmina. 2013. Determination of Cost of Production Based on Full Costing Method in Making Etasale Glass and Aluminiun at UD. Manado aluminum palace. EMBA Journal vol 1 no 3 p. 217224. Economics Faculty of Accounting: Sam Ratulangi University, Manado

[14] Ratung, valentine et al. 2015 Selling With Costing Variable Methods And Activity Based Costing At PT. Massindo Sinar Pratama Industri. EMBA Journal vol. 3 no 3. Page 1341-1348. Economics and Business Faculty of Kuntansi Department: Sam Ratulangi University, Manado 